\title{
Kajian Kuat Tekan Beton Normal Menggunakan Standar SNI 7656-2012 Dan ASTM C 136-06
}

\author{
Arman. A \\ Dosen Jurusan Teknik Sipil, Institut Teknologi Padang \\ Email: arman.agung@yahoo.com,
}

\begin{abstract}
Abstrak: Beton merupakan salah satu pilihan sebagai bahan struktur dalam kontruksi bangunan. Inovasi teknologi beton selalu dituntut guna menjawab tantangan akan kebutuhan, beton yang dihasilkan diharapkan mempunyai kwalitas tinggi meliputi kekuatan dalam daya tahan tanpa mengabaikan nilai ekonomis. Peraturan mengenai standar spesifikasi agregat di indonesia mengalami perubahan seiring dikeluarkannya SNI 7656-2012 dan ASTM C 136-06 yang mengenai persyaratan Spesifikasi agregat untuk perencanaan beton. Salah satu hal baru yang tercantum dalam SNI 76562012 adalah dalam hal penentuan gradasi saringan di tetapkan dalam zona-zona yang telah di tentukan, hal ini sedikit berbeda dari peraturan ASTM C 136-06 yang menyatakan bahwa spesifiksi gradasi telah di tentukan. Penelitian ini bersifat eksperiment yang dilaksanakan dilaboratorium teknik sipil Institut Teknologi Padang (ITP). Objek pada penelitian ini adalah beton dengan mutu sedang yang menggunakan bahan Standar SNI 7656-2012 dan ASTM C 136-06. Pembuatan benda uji yang digunakan berbentuk kubus berukuran lebar $15 \mathrm{~mm}$ x tinggi $15 \mathrm{~mm}$ x Panjang $15 \mathrm{~mm}$. Sebanyak (3) sampel tiap variasi campuran yang berbeda dengan umur beton 7,14,dan 28 hari. Rata - rata nilai pengujian kuat tekan beton kubus umur 7 hari degan suhu air $25^{\circ} \mathrm{C}$ proses pengerjaan pada pagi hari Standar SNI 7656-2012 sebesar $171,55 \mathrm{Kg} / \mathrm{m}^{2}$ dan Standar ASTM C 136-06 sebesar $166,72 \mathrm{Kg} / \mathrm{m}^{2}$ dengan persen perbandingan kuat tekan sebesar 3\%. Sementara pada benda uji kubus umur 14 hari dengan suhu air $28^{\circ} \mathrm{C}$ proses pengerjaan pada siang hari Standar SNI 7656-2012 sebesar 222,30 $\mathrm{Kg} / \mathrm{m}^{2}$ dan Standar ASTM C 136-06 sebesar 210,22 Kg/m² dengan persen perbandingan kuat tekan sebesar 5\%. Setelah dilakukan pembuatan benda uji dengan suhu air $25^{\circ} \mathrm{C}$ langsung perawaatan benda uji, kubus umur 28 hari mengalami peningkatan kuat tekan beton peroleh nilai Standar SNI 7656-2012 sebesar 267,60 Kg/m² dan Standar ASTM C 136-06 sebesar 264,58 Kg/m ${ }^{2}$ dengan persen perbandingan kuat tekan sebesar 1\%. Berdasarkan analisis dan pembahasan dapat disimpulkan bahwa Job Mix Design beton metode ASTM C 136-06 menghasilkan proporsi campuran bahan yang relative lebih efisien dibandingkan metode SNI 7656-2012. Artinya bahwa secara teoritis Job Mix Design beton fc' $20.75 \mathrm{MPa}$ metode ASTM C 136-06 lebih ekonomis dari segi penggunaan bahan dari metode SNI 7656-2012.
\end{abstract}

Kata Kunci: Metode SNI 7656-2012, ASTM C 136-06, Beton Normal, Kuat Tekan Beton.

\section{PENDAHULUAN}

Pembangunan dibidang struktur saat ini mengalami kemajuan yang sangat pesat, yang berlangsung diberbagai bidang, misalnya gedung-gedung, jembatan, tower, dan sebagainya. Beton merupakan salah satu pilihan sebagai bahan struktur dalam konstruksi bangunan. Hal ini dikarnakan banyaknya kelebihan-kelebihan beton dibandingkan dengan bahan lainnya, antara lain harganya yang relatif murah, mempunyai kekuatan yang baik, bahan baku penyusun mudah didapat, tahan lama, tahan terhadap api, tidak mengalami pembusukan. Inovasi teknologi beton selalu dituntut guna menjawab tantangan akan kebutuhan, beton yang dihasilkan diharapkan mempunyai kwalitas tinggi meliputi kekuatan dan daya tahan tanpa mengabaikan nilai ekonomis. Sifat fisis material sangat mempengaruhi mutu dan spesifikasi beton tersebut. Hal lain yang mendasari pemilihan dan penggunaan beton sebagai bahan konstruksi adalah factor efektifitas dan tingkat efisiensinya. Secara umum bahan pengisi beton terbuat dari bahanbahan yang mudah diperoleh, mudah diolah (workability) dan mempunyai keawetan (durability) sertake kuatan(strength) yang sangat diperlukan dalam suatu konstruksi. Dari sifat yang dimiliki beton itulah menjadikan beton sebagai bahan alternatif untuk dikembangkan baik bentuk fisik maupun metode pelaksanaannya.

$\begin{array}{lr}\text { Fakultas Teknik UMSB } & \text { ISSN 2599-2081 } \\ \text { EISSN 2599-2090 }\end{array}$


Peraturan mengenai standar spesifikasi agregat di Indonesia mengalami perubahan seiring dikelurkannya SNI 7656-2012 dan ASTM C 136-06 yang mengenai persyaratan spesifikasi agregat untuk perencanaan beton, meskipun tidak terdapat perubahan yang segnifikan namun beberapa perubahan yang di ataur oleh SNI dan ASTM yang baru ini harus dipahami dengan baik oleh pelaku kontruksi, terutama pada perencanaan rancangan campuran beton. Salah satu hal baru yang tercantum dalam SNI 7656 - 2012 adalah dalam hal analisa saringan agreggat dimana saringan terdiri dari 1,5”, 3/4", 3/8", No 4", No 8 ", No 16". Serta penentuan gradasi saringan ditetapkan dalam zona - zona yang telah ditentukan antara lain Zona 1, Zona II, Zona III, danZona IV. Hal ini sedikit berbeda dari peraturan ASTM C 136 - 06 yang menyatakan bahwa, analisa saringan agreggat terdiri dari 1 ", 3/4", 1/2", 3/8", No 4", No 8". Selain itu perubahan juga terjadi dispesifikasi gradasi, dimana spesifikasi gradsi telah ditentukan.

Berbagai penelitian dan percobaan dibidang beton dilakukan sebagai upaya untuk meningkatkan kualitas beton. Penelitian sejenis pernah dilakukan dengan judul "PERBANDINGAN JOB MIX DESIGN BETON METODE DoE DAN ASTM”, Berdasarkan analisis dan pembahasan dapat disimpulkan bahwa Job Mix Designbeton metode ASTM menghasilkan proporsi campuran bahan yang relatif lebih efisien dibandingkan metode DoE. Artinya bahwa secara teoritis Job Mix Design beton fc' 22,5 MPa metode ASTM lebih ekonomis dari segi penggunaan bahan dari metode DoE. oleh Hidayat, Arifal (2014).

Teknologi bahan dan teknik-teknik pelaksanaan yang di peroleh dari hasil penelitian dan percobaan tersebut dimaksudkan untuk menjawab tuntutan yang semakin tinggi terhadap pemakaian beton serta mengatasi kendala-kendala yang sering terjadi pada pengerjaan dilapangan.

\section{TINJAUAN PUSTAKA \\ Beton Normal}

Beton adalah campuran antara semen Portland atau semen hidraulik lainnya, agregat halus, agregat kasar, dan air, dengan atau tanpa bahan tambahan yang membentuk masa padat (SNI-03-2847-2012).

\section{Standar SNI 7656 - 2012}

Standar SNI merupakan satu - satunya standar untuk semua produk atau tata - tata tertib pekerjaan yang berlaku secara nasional di Indonesia. SNI disusun oleh Panitia Teknis dan ditetapkan oleh BNS yaitu untuk membina, menembangkan serta mengkoordinasikan kegiatan di bidang standarlilasi secara nasional. Metode dalam SNI 7656-2012 ini mengadopsi beberapa asumsi sebagai berikut:

a. Metode ini tidak membedakan jenis semen hidrolik (berlaku untuk semua jenis semen hidrolik) dan jenis agregat;

b. Konsistensi campuran yang mempengaruhi kemudahan kerja dianggap hanya tergantung pada kadar air bebas dari proporsi campuran, dinyatakan dalam uji slump, uji $\mathrm{VeBe}$ atau uji faktor pemadatan;

c. Rasio optimum dari volume curah agregat kasar per kubik beton tergantung hanya pada ukuran maksimum nominal agregat kasar dan gradasi agregat halus;

d. Jenis pemadatan berpengaruh pada tinggi slump yang dianjurkan;

e. Estimasi volume bahan campuran beton dapat dilakukan berdasarkan ekivalensi berat maupun ekivalensi volume absolut;

f. Metode ini tidak memberikan batasan kadar minimum beton yang dapat digunakan;

g. Metode ini memberikan pengurangan air sebesar $18 \mathrm{~kg} / \mathrm{m} 3$ pada campuran beton yang menggunakan agregat kasar alami/kerikil.

Standar ASTM C 136 - 06

ASTM (American Society For Testing And Material) dibentuk pertama kali pada tahun 1898 oleh sekelompok insinyur dan ilmuwan untuk mengatasi bahan - bahan yang bermasalah. Metode uji ini digunakan terutama untuk menentukan gradasi bahan yang diusulkan untuk digunakan sebagai agregat. Hasilnya digunakan untuk menentukan kesesuaian distribusi ukuran partikel dengan 
persyaratan spesifikasi yang berlaku dan untuk menyediakan data yang diperlukan untuk pengendalian produksi berbagai produk agregat dan campuran yang mengandung agregat.

\section{Material Penyusun Beton}

\subsubsection{Semen portland (PC)}

Semen portland ditemukan oleh Joseph Aspdin pada tahun 1824. Menurut ASTM C150,1985 , semen portland didefenisikan sebagai semen hidrolik yang dihasilkan dengan cara menggilingkan klinker yang terutama terdiri dari kalsium selikat hidrolik yang pada umumnya mengandung satu atau lebih bentuk kalsium sulfat sebagai bahan tambahan yang digilingi bersama-sama dengan bahan utamanya. Semen sebagai pengikat hidrolis (bahan yang mengeras setelah bersenyawa dengan air) mengikat agregat agar terjadi suatu massa yang kompak/padat pada beton serta mengisi rongga-rongga diantara butiran agregat. Spesifikasi pemakaian semen mengacu pada SNI-15-2049-1994.

\subsubsection{Agregat}

Agregat terbagi atas agregat halus dan agregat kasar yang merupakan material alami sebagai pengisi dalam campuran beton kirakira menempati sebanyak $70 \%-75 \%$ dari volume beton.

a. Agregat kasar

Agregat kasar adalah material (kerikil) hasil disintegrasi bumi dari batuan alam atau berupa batu pecah (split) dengan ukuran butir lebih besar atau sama dengan 4,75 $\mathrm{mm}(3 / 16 \mathrm{in})$ atau yang saringan no. 4 standar ASTM C33-93.

b. Agregat halus

Agregat halus adalah butiran mineral alami yang memiliki butiran lebih kecil dari 4,75 mm (3/16 in) atau yang lolos saringan no 4 standar ASTM C 33-93. Agregat halus dapat berupan pasir alam, hasil disintegrasi batu alam atau debu hasil pecahan batu (crusher).

\subsubsection{Air}

Air diperlukan pada pembuatan beton untuk memicu proses kimiawi semen, membasahi agregat dan memberikan kemudahan dalam pekerjaan beton. Air yang mengandung senyawa-senyawa yang berbahaya, yang tercemar garam, minyak, gula atau bahan kimia lainnya, bila dipakai dalam campuran beton akan menurunkan kualitas beton, bahkan dapat mengubah sifat-sifat beton yang dihasilkan (Mulyono, 2005).

Air yang berlebihan akan menyebabkan banyaknya gelembung air setelah proses hidrasi selesai, sedangkan air yang terlalu sedikit akan menyebabkan proses hidrasi tidak tercapai seluruhnya, sehingga akan mempengaruhi kekutan beton.

Menurut (Pramono dan Suryadi, 1998), dalam pemakaian air untuk beton itu sebaiknya air memenuhi syarat sebagai berikut:

a. Tidak mengandung lumpur lebih dari 2 gram/liter

b. Tidak mengandung garam-garam yang dapat merusak beton lebih dari 15 gram

c. Tidak mengandung khlorida $(\mathrm{Cl})$ lebih dari 0,5 gram/liter

d. Tidak mengandung senyawa sulfat lebih dari 1 gram/liter

\section{Adukan Beton}

Pada umunya pengadukan beton normal dilakukan dengan menggunakan mesin. Kekentalan adukan beton dikendalikan dengan cara memeriksa slump pada setiap adukan beton baru. Nilai slump digunakan sebagai petunjuk ketepatan jumlah pemakaian air dalam hubungannya dengan faktor air semen yang ingin dicapai.

\section{Percobaan Pendahuluan (Trial Mixing)}

Percobaan pendahuluan yaitu membuat campuran percobaan (trial mixes) seperti komposisi yang telah di dapatkan dalam mix desain untuk memastikan hasilnya, apakah campuran benar-benar mencapai kekuatan yang direncanakan (Samekto dan Rahmadiyanto, 2001: 70). Menurut (SNI-032847-2002) untuk beton mutu Bo dapat Dipakai campuran dengan syarat bahwa perbandingan jumlah pasir dan kerikil terhadap jumlah semen, tidak boleh melampaui 8:1.

\section{Test Slump}

Uji Slump adalah suatu uji empiris/metode yang digunakan untuk menentukan konsistensi/kekakuan (dapat dikerjakan atau tidak) dari campuran beton 
segar (fresh concrete) untuk menentukan tingkat workabilitynya.

\section{Kuat Tekan Beton}

Kekuatan tekan adalah kemampuan beton untuk menerima gaya tekan persatuan luas. Kuat tekan beton mengidentifikasikan mutu dari sebuah struktur. Semakin tinggi tingkat kekuatan struktur yang dikehendaki, semakin tinggi pula mutu beton yang dihasilkan.

Nilai kuat tekan beton didapatkan melalui tata cara pengujian standar, menggunakan mesin uji dengan cara memberikan beban tekan bertingkat pada benda uji kubus sampai hancur. Untuk standar pengujian kuat tekan digunakan SNI 03- 6805 - 2002 dan ASTM C 39/C 39M-04a.

$$
\sigma=\frac{P}{A}
$$

Dimana $\sigma$ merupakan kuat tekan benda uji $\left(\mathrm{kg} / \mathrm{cm}^{2}\right)$ dan $\mathrm{P}$ merupakan besar beban maksimum $(\mathrm{Kg})$ dan $\mathrm{A}$ merupakan luas penampang benda uji $\left(\mathrm{cm}^{2}\right)$.

\section{Perawatan Beton (Curing)}

Curing merupakan suatu usaha perawatan beton setelah beton dicor yang wajib dilakukan, karena bertujuan untuk memastikan reaksi hidrasi senyawa semen termasuk bahan tambahan atau pengganti agar dapat berlangsung secara optimal sehingga mutu beton yang diharapkan dapat tercapai, dan menjaga supaya tidak terjadi susut yang berlebihan pada beton akibat kehilangan kelembaban yang terlalu cepat atau tidak seragam, sehingga dapat menyebabkan retak.

Curing dapat dilakukan dengan berbagai macam cara antara lain :

1. Menyemprotkan dengan lapisan khusus (semacam Vaseline) pada permukaan beton.

2. Membasahi secara terus menerus permukaan beton dengan air. Setelah proses curing, di lakukan pengurugan tanah kembali lapis demi lapis.

\section{METODE PENELITIAN \\ Prosedur Penelitian}

Secara garis besar prosedur penelitian ini mempunyai tahapan yang bisa dilihat pada bagan alir pada gambar 3.1. di bawah ini:

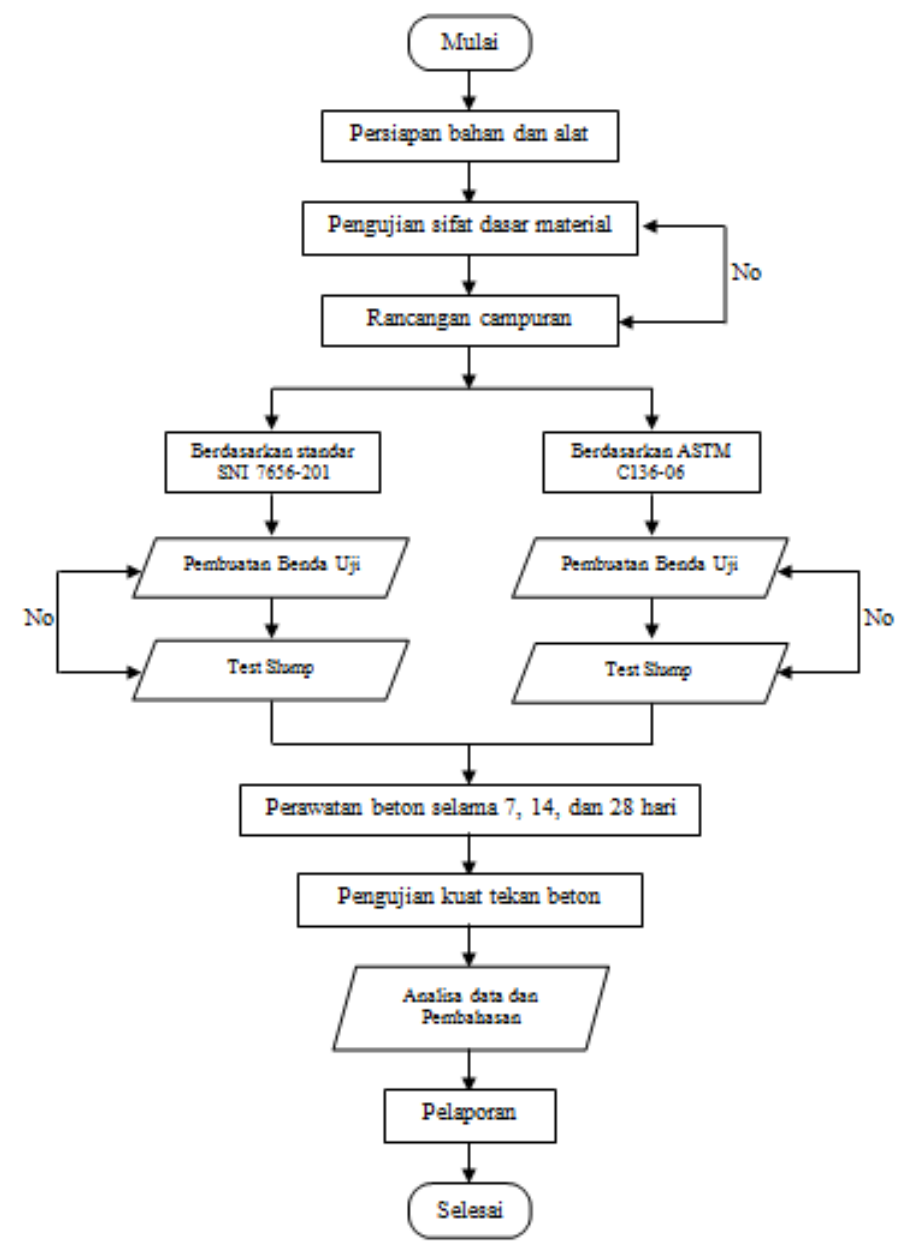

Gambar 1. Bagan alir pelaksanaan penelitian

\section{Bahan Penelitian}

Bahan yang digunakan dalam pengadukan beton adalah sebagai berikut:

1. Semen Portland, menggunakan jenis Portland Composite Cement (PCC) produksi PT. Semen Padang.

2. Aggregat kasar, menggunakan Split 1 - 2 dan 1/2 - 1 dari CV. Barokah.

3. Aggregat halus, menggunakan pasir alam berasal dari quari sungai daerah Gunung Nago, Kota Padang

4. Air yang sumber dari PDAM di laboratorium Institut Teknologi Padang (ITP). 


\section{Alat yang digunakan dalam Penelitian}

Alat yang digunakan dalam penelitian adalah sebagai berikut:

1. Cetakan kubus

2. Oven

3. Piring logam

4. Mesin Shaker

5. Ayakan

6. Timbangan

7. Gelas ukur

8. Ember

9. Kerucut Abraham

10. Mixer

11. Sekop

12. Kaliper

13. Universal Testing Machine (UTM)

14. Kolam penampung

\section{Benda Uji}

Pembuatan benda uji yang akan digunakan berbentuk kubus dengan ukuran 150 $\times 150 \times 150 \mathrm{~mm}$ sebanyak 3 (dua) sampel tiap variasi campuran, seperti yang dipaparkan pada Tabel 1 berikut:

Tabel 1. Tabel benda uji

\begin{tabular}{|l|c|c|c|c|}
\hline \multirow{2}{*}{$\begin{array}{c}\text { Variasi Campuran } \\
\text { Beton }\end{array}$} & \multicolumn{3}{|c|}{$\begin{array}{c}\text { Waktu } \\
\text { Pengujian } \\
\text { (hari) }\end{array}$} & \multirow{2}{*}{$\begin{array}{c}\text { Jumla } \\
\text { h }\end{array}$} \\
\cline { 2 - 4 } & $\mathbf{7}$ & $\mathbf{1 4}$ & $\mathbf{2 8}$ & \\
\hline $\begin{array}{l}\text { Campuran beton } \\
\text { dengan Standar SNI } \\
\text { 7656-2012 }\end{array}$ & 3 & 3 & 3 & 9 \\
\hline $\begin{array}{l}\text { Campuran beton } \\
\text { dengan Standar } \\
\text { ASTM C 136-06 }\end{array}$ & 3 & 3 & 3 & 9 \\
\hline \multicolumn{4}{|l|}{ Total Jumlah Sample } & $\mathbf{1 8}$ \\
\hline
\end{tabular}

\section{Pelaksanaan Penelitian}

Penelitian diawali dengan pengadaan material (agregat halus adalah pasir dan agregat kasar adalah kerikil). Setelah material didapat, dilakukan pengujian sifat dasarnya dengan tahapan sebagai berikut:

1. Pemeriksaan gradasi agregat

2. Pemeriksaan kotoran agregat

3. Pemeriksaan passing No. 200

4. Pemeriksaan berat isi agregat

5. Pemeriksaan berat jenis dan penyerapan agregat

6. Pemeriksaan keausan agregat dengan mesin Los Angeles

Selanjutnya dilakukan pembuatan rancangan campuran beton (mix design) berdasarkan metoda SK SNI T-15-1990-03. Setelah data rancangan campuran beton diperoleh, maka pekerjaan selanjutnya adalah pembuatan benda uji sebanyak 18 buah sampel yang terdiri dari 9 sampel campuran beton dengan standar SNI dan 9 sampel dari campuran beton dengan standar ASTM . Benda uji yang digunakan berbentuk kubus dengan ukuran $150 \times 150 \times 150 \mathrm{~mm}$.

Selama umur rencana, benda uji dimasukan ke dalam bak perendam sebagai perawatan beton (curing). Jika umur rencana telah terpenuhi selanjutnya dilakukan pengujian kuat tekan beton sesuai standar pengujian SNI 7656-2012 dan ASTM C 13606 dengan menggunakan Universal Testing Machine (UTM). Berdasarkan data yang diperoleh melalui kuat tekan beton maka perkerjaan terakhir yang dilakukan adalah menganalisis data untuk membuat kesimpulan.

\section{HASIL DAN PEMBAHASAN \\ Pengujian Agregat Halus \\ Standar SNI 7656-2012}

Berdasarkan hasil dari pemeriksaan agregat halus material yang digunakan dalam penelitian ini memenuhi spesifikasi gradasi sesuai standar, masuk pada zona II (pasir kasar) dengan modulus kehalusan $(\mathrm{fm})=3,45$. Kadar kotoran organik didapat warna yang sesuai dengan warna No. 3 pada tintometer. Pemeriksaan lolos saringan No. 200 sebesar $2,6 \%$. Berat isi agregat halus sebesar 1,40 $\mathrm{gr} / \mathrm{cm}^{3}$. Hasil ini menunjukan bahwa pasir yang akan digunakan tersebut memenuhi standar SNI 7656-2012 dengan standar minimal $1,2 \mathrm{gr} / \mathrm{cm}^{3}$. Berat jenis pada pasir kering 2,43, berat jenis SSD 2,49, berat jenis apparent 2,59 , dan penyerapan $2,52 \%$, terlihat bahwa agregat halus memenuhi standar SNI 7656-2012 dengan standar Bj minimal 2,3 dan penyerapan air maksimal 5\%. Dari hasil pengujian Send Equivalent diperoleh nilai SE sebesar 2,9\%, yang menyatakan bahwa pasir tersebut memenuhi standar SNI 7656-2012 dengan standar nilai Sand Equivalent maksimal $5 \%$.

\section{Standar ASTM C 136-06}

Berdasarkan hasil dari pemeriksaan agregat halus material yang digunakan dalam
146
Fakultas Teknik UMSB
ISSN 2599-2081
EISSN 2599-2090 
penelitian ini memenuhi spesifikasi gradasi sesuai standar, masuk pada zona II (pasir kasar) dengan modulus kehalusan $(\mathrm{fm})=3,45$. Kadar kotoran organik didapat warna yang sesuai dengan warna No. 3 pada tintometer. Pemeriksaan lolos saringan No. 200 sebesar $3,0 \%$. Berat isi agregat halus sebesar 1,40 $\mathrm{gr} / \mathrm{cm}^{3}$. Hasil ini menunjukan bahwa pasir yang akan digunakan tersebut memenuhi standar ASTM C 136-06 dengan standar minimal $1,2 \mathrm{gr} / \mathrm{cm}^{3}$. Berat jenis pada pasir kering 2,44, berat jenis SSD 2,49, berat jenis apparent 2,58, dan penyerapan $2,31 \%$, terlihat bahwa agregat halus memenuhi standar ASTM C 136-06 dengan standar $\mathrm{Bj}$ minimal 2,3 dan penyerapan air maksimal 5\%.

\section{Pengujian Agregat Kasar Standar SNI 7656-2012}

Hasil pengujian menyimpulkan bahwa agregat kasar yang digunakan memiliki ukuran butiran max $40 \mathrm{~mm}$ (SNI 7656-2012) dengan modulus kehalusan sebesar 7,13, masuk pada zona 1. Pemeriksaan lolos saringan No. 200 sebesar $0,9 \%$. Pemeriksaan berat isi agregat kasar split 1 - 2 sebesar $1,4 \mathrm{gr} / \mathrm{cm}^{3}$ dan berat isi agregat kasar split $1 / 2-1$ sebesar $1,3 \mathrm{gr} / \mathrm{cm}^{3}$. Berat jenis kering 2,59, berat jenis SSD 2,65, berat jenis apparent 2,75, dan penyerapan air $2,25 \%$ untuk agregat kasar split 1 - 2. Berat jenis kering 2,43, berat jenis SSD 2,51, berat jenis apparent 2,65, dan penyerapan air 3,48\% untuk agregat kasar split $1 / 2-1$, terlihat bahwa agregat kasar memenuhi standar SNI 76562012 dengan standar $\mathrm{Bj}$ minimal 2,3 dan penyerapan air maksimal 5\%. Nilai keausan agregat kasar dengan mesin los angeles adalah $20,04 \%$. Berarti nilai keausan agregat memenuhi standar batas max yang diizinkan $($ spec $)=$ Max. 27\% - 30\% (7656-2012).

\section{Standar ASTM C 136-06}

Hasil pengujian menyimpulkan bahwa agregat kasar yang digunakan memiliki ukuran butiran max $40 \mathrm{~mm}$ (ASTM C 136-06) dengan modulus kehalusan sebesar 7,13, masuk pada zona 1. Pemeriksaan lolos saringan No. 200 sebesar $0,6 \%$. Pemeriksaan berat isi agregat kasar split 1 - 2 sebesar $1,4 \mathrm{gr} / \mathrm{cm}^{3}$ dan berat isi agregat kasar split $1 / 2-1$ sebesar $1,3 \mathrm{gr} / \mathrm{cm}^{3}$. Berat jenis kering 2,53, berat jenis SSD 2,58, berat jenis apparent 2,68, dan penyerapan air
2,25\% untuk agregat kasar split 1 - 2. Berat jenis kering 2,70, berat jenis SSD 2,79, berat jenis apparent 2,97, dan penyerapan air 3,46\% untuk agregat kasar split $1 / 2-1$, terlihat bahwa agregat kasar memenuhi standar ASTM C 13606 dengan standar $\mathrm{Bj}$ minimal 2,3 dan penyerapan air maksimal 5\%. Nilai keausan agregat kasar dengan mesin los angeles adalah $16,2 \%$. Berarti nilai keausan agregat memenuhi standar batas max yang diizinkan $($ spec $)=$ Max. $27 \%-30 \%$ (ASTM C 136-06).

\section{Perencanaan Campuran Beton (Mix Design)}

Berdasarkan hasil dari perencanaan rancangan beton, diperoleh hasil akhir untuk komposisi campuran beton $/ \mathrm{m}^{3}$ dan komposisi campuran beton untuk 9 buah benda uji beton normal yang tercantum dalam table 2 dan 3 berikut:

Tabel 2. Komposisi campuran beton normal $/ \mathrm{m}^{3}$

\begin{tabular}{|l|l|l|l|l|}
\hline \multirow{2}{*}{ No } & \multirow{2}{*}{$\begin{array}{l}\text { Komposisi } \\
\text { Bahan } / \mathbf{m}^{3}\end{array}$} & $\begin{array}{l}\text { SNI } \\
\mathbf{7 6 5 6 -} \\
\mathbf{2 0 1 2}\end{array}$ & $\begin{array}{l}\text { ASTM C } \\
\mathbf{1 3 6 - 0 6}\end{array}$ & Satuan \\
\hline 1 & Semen & 390 & 390 & $\mathrm{Kg}$ \\
\hline 2 & Air & 255,71 & 210 & $\mathrm{Kg} / \mathrm{Ltr}$ \\
\hline 3 & Pasir & 629,72 & 696 & $\mathrm{Kg}$ \\
\hline 4 & Split $1-2$ & 475,88 & 534,9 & $\mathrm{Kg}$ \\
\hline 5 & Split 1 /2 - 1 & 556,07 & 504,6 & $\mathrm{Kg}$ \\
\hline
\end{tabular}

Tabel 3. Komposisi campuran beton normal untuk 9 buah benda uji

\begin{tabular}{|r|l|l|l|l|}
\hline \multirow{2}{*}{ No } & \multirow{2}{*}{$\begin{array}{c}\text { Komposisi } \\
\text { Bahan }\end{array}$} & $\begin{array}{l}\text { SNI 7656- } \\
\mathbf{2 0 1 2}\end{array}$ & ASTM C 136-06 & Satuan \\
\hline 1 & Semen & 11,84 & 11,84 & $\mathrm{Kg}$ \\
\hline 2 & Air & 7,77 & 7,78 & $\mathrm{Kg} / \mathrm{Ltr}$ \\
\hline 3 & Pasir & 19,12 & 20,65 & $\mathrm{Kg}$ \\
\hline 4 & Split $1-2$ & 14,45 & 16,38 & $\mathrm{Kg}$ \\
\hline 5 & Split 1/2 - 1 & 16,89 & 14,79 & $\mathrm{Kg}$ \\
\hline
\end{tabular}

\section{Pengujian Kuat Tekan Beton}

Dari hasil pengujian kuat tekan yang dilakukan dilaboratorium, didapatkan nilai kuat tekan yang dipaparkan pada Tabel 5. Gambar 2 merupakan grafik perbandingan kuat tekan rata-rata. 
Tabel 4. Hasil Kuat Tekan Beton Rata-rata

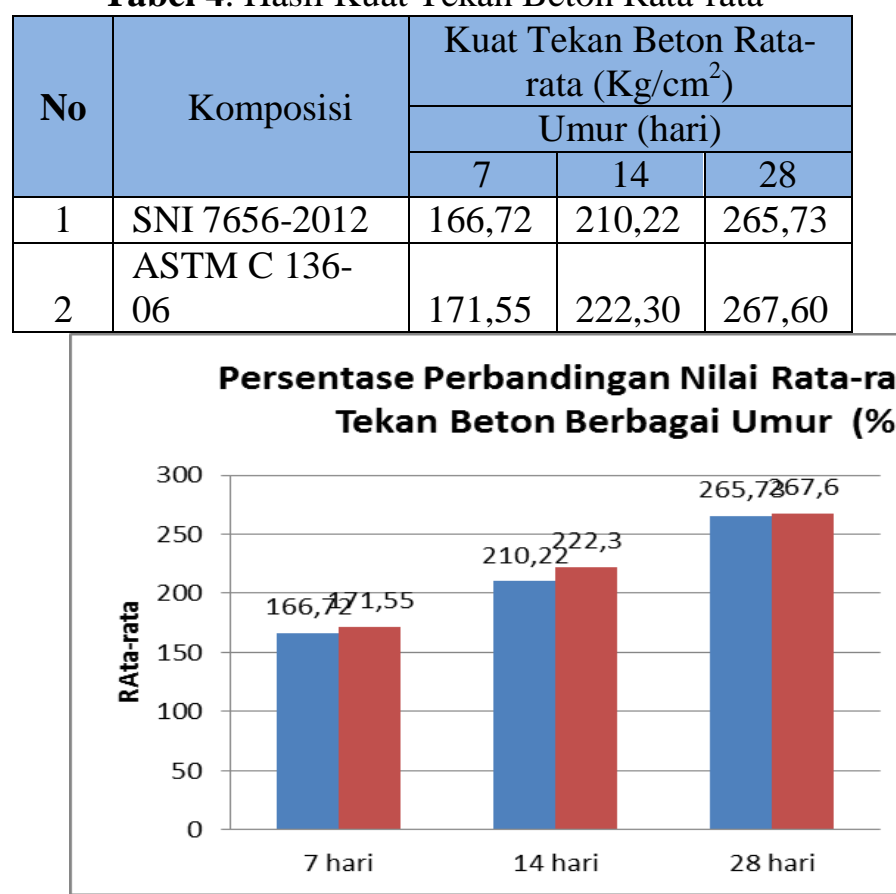

Gambar 2. Grafik perbandingan kuat tekan rata-rata

\section{SIMPULAN}

Berdasarkan hasil penelitian nilai kuat tekan beton dengan kajian kuat tekan beton normal dengan standar SNI 7656-2012 dan ASTM C 136-06 :

1. Kuat tekan beton terhadap kubus umur 28 hari perbandingan Standar SNI 7656-2012 sebesar $267,60 \mathrm{Kg} / \mathrm{m}^{2}$ dan Standar ASTM C $136-06$ sebesar $264,58 \mathrm{Kg} / \mathrm{m}^{2}$ dengan persen perbandingan kuat tekan sebesar $1 \%$.

2. Pada umur 14 hari didapatkan kuat tekan beton pada Standar SNI 7656-2012 sebesar 222,30 Kg/m² dan Standar ASTM C 136-06 sebesar 210,22 Kg/m² dengan persen perbandingan kuat tekan sebesar $5 \%$.

3. Sedangkan umur 7 hari didapatkan kuat tekan beton pada Standar SNI 7656-2012 sebesar $171,55 \mathrm{Kg} / \mathrm{cm}^{2}$ dan Standar ASTM C 136-06 sebesar $166,72 \mathrm{Kg} / \mathrm{m}^{2}$ dengan persen perbandingan kuat tekan sebesar $3 \%$.

4. Pemeriksaan agregat menggunakan Standar SNI 7656-2012 lebih halus di bandingan dengan Standar ASTM C 136062012.

5. Berdasarkan analisis dan pembahasan dapat disimpulkan bahwa Job Mix Design beton metode ASTM C 136-06 menghasilkan proporsi campuran bahan yang relatif lebih efisien dibandingkan metode SNI 7656-2012. Artinya bahwa secara teoritis Job Mix Design beton fc' 20.75 MPa metode ASTM lebih ekonomis dari segi penggunaan bahan dari metode SNI 7656-2012.

\section{uat}

\section{DAFTAR PUSTAKA}

Arman, A., Herman, H., \& Aditya, W., (2014), Studi Desain Campuran Pasir Gunung (Ex Lubuk Alung) Terhadap Kuat - SNI 765Eekan Beton Normal, Jurnal - ASTM AM@mentum ISSN: 1693-752X, 16(2).10

A.S.T.M., (1993), Compressive Strength of Cylindrical Concrete, Annual Book of ASTM Standards Vol.04.01, Phiadelphia.

Cordon, W. A. dan Gillespie, H. A., (1963), Variables in Concrete Aggregates and Portland Cement Paste which Influence the Strength of Concrete, ACI Journal Proceedings, 60(8), 10291052.

Fuad, I. S., Asmawi, B., \& Dibuat, H., (2015), Pengaruh Penggunaan Pasir Sungai dengan Pasir Laut Terhadap Kuat Tekan dan Lentur Pada Mutu Beton K225. Journal from \#PUBLISHER 13(11), 09.

SNI 03 - 2847 - 2002, (2002), Tata Cara Perhitungan Struktur Beton Untuk Bangunan Gedung (Beta Version) Risdiyanto, Y., (2013), Kajian Kuat Tekan Beton dengan Perbandingan Volume dan Perbandingan Berat untuk Produksi Beton Massa menggunakan Agregat Kasar Batu Pecah Merapi (Studi Kasus pada Proyek Pembangunan Sabo Dam). Skipsi UMY.

Tjokrodimuljo, K., 2007, Teknologi Beton, Biro Penerbit Teknik Sipil Keluarga Mahasiswa Teknik Sipil dan Lingkungan, Universitas Gadjah Mada Yogyakarta.

Wang, C. K., dan Salmon, C. G., (1999), Disain beton bertulang, jilid 1 , Erlangga, Jakarta.

\footnotetext{
148 